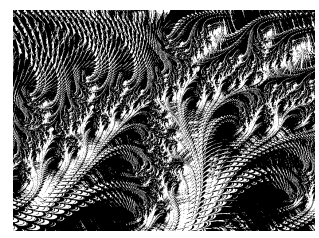

https://doi.org/10.5559/di.30.4.02

\title{
WHO AND WHAT HOLDS BACK REFORMS \\ IN CROATIA? \\ - THE POLITICAL \\ ECONOMY PERSPECTIVE
}

Valentina VUČKOVIĆ

Faculty of Economics and Business, University of Zagreb,

Zagreb, Croatia

Ružica ŠIMIĆ BANOVIĆ

Faculty of Law, University of Zagreb,

Zagreb, Croatia

UDK: $33.021 .8(497.5)$

$328.18(497.5)$

Original scientific paper

Received: August 15, 2019

The purpose of this paper is to explore the factors affecting reform patterns in Croatia in order to identify the main reasons for the (missing) reform success so far. The focus is on the analysis of the political system, especially on government fragmentation as one of the main features of proportional electoral rule and clientelism. In addition to political variables, economic factors are analysed as well. The obtained results show that reforms in Croatia were implemented during crises, that coalition governments are not conducive to reforms and that clientelism and corruption present significant obstacles for reform implementation in Croatia. Moreover, the results show that political cycles also have a significant effect, with reform activity slowing down as elections approach. This article contributes to the burgeoning debate on reform implementation (in the post-socialist societies) from the political economy perspective.

Keywords: reforms, Croatia, clientelism, coalitions, corruption, economic freedom

$\triangle \quad$ Valentina Vučković, Department of Economic Theory, Faculty of Economics and Business, University of Zagreb, Trg J. F. Kennedyja 6, 10000 Zagreb, Croatia. 
Structural reforms, usually being associated with regulatory policies strengthening market-based incentives, can be analysed in many areas such as product and service markets, labour markets, trade, capital and financial markets (Kouamé \& Tapsoba, 2018, p. 3). However, the common characteristic of reform implementation in all areas, is that it is a complex and difficult process, while desired outcomes are not always fully achieved (Meunier \& Zaman, 2015, p. 1).

In this paper, we focus on one of the fundamental issues at the centre of economic and political science when analysing reforms, i.e., on the analysis of political and economic determinants of reforms (Krueger, 1995, p. 4). When analysing reforms in the Western Balkans countries, Bartlett (2008) points out that Croatia (as one of the early reformer countries), while having successfully implemented reforms at the macroeconomic level, did not simultaneously implement structural reforms at the microeconomic level. As a result, at the end of the 1990s, the country found itself in problems that still persist today. These are, among others, found in the healthcare system, pension system, taxation, labour market, social rights, business environment etc. Numerous international benchmarks and reports (e.g., World Bank Doing Business, World Economic Forum Global Competitiveness Report) have also been implying the necessity of structural reforms in Croatia. Also, the most recent European Commission report (EC, 2019, $\mathrm{Ch} 2$ ) stresses that since the start of the European Semester in 2014, a total of $51 \%$ of all country-specific recommendations for reform implementation in Croatia have reached at least some progress. Yet, within these $51 \%$, only $7 \%$ of them have been fully implemented, $12 \%$ have recorded substantial progress and 32\% recorded some progress. In addition, 19\% of all country-specific recommendations have not recorded any progress and 30\% have recorded limited progress.

On the other hand, the need for reforms, with the main goal of improving the country's economic performance and resolving some of the issues in the above stated areas, became a sort of mantra of all governments in Croatia that has perpetually been present on their agenda, regardless of their ideology. Despite the recognised need for implementing them, reforms were either slow, limited or non-existent. Thus, the main goal of this paper is to analyse factors that encourage or undermine policy makers in implementing structural reforms in Croatia. As key actors involved in the process estimate the potential benefits and costs of it, where benefits can take on various forms: economic (cost-cutting), ideological (close to the policy-makers' ideological position) and/or political (implementing reforms can make policy makers more popular increasing 
DRUŠ. ISTRAŽ. ZAGREB GOD. 30 (2021), BR. 4, STR. 675-698

VUČKOVIĆ, V., ŠIMIĆ BANOVIC, R.

WHO AND WHAT.. the probability of winning the elections) (Castanheira et al., 2006), it is reasonable to expect that reforms depend on various characteristics (economic, social, institutional, political etc.) of a particular country.

The paper is structured as follows. After the introduction, Section 2 describes the methodological challenges related to defining and measuring reforms. Section 3 reviews previous theoretical and empirical literature and argues for the choice of indicators that will be used in the econometric analysis performed in Section 4. Finally, Section 5 concludes the analysis and provides the recommendations for future research.

\section{DEFINING AND MEASURING REFORMS}

As there is no single definition of the term structural reforms, four intertwined terms are often taken as synonymous. These are the: (1) product market reforms; (2) regulatory reforms; (3) structural reforms and (4) microeconomic reforms (Pelkmans, 2010). In broad terms, we can speak of first- and second-generation reforms. When analysing structural reforms, various authors have usually referred to a set of first-generation reforms contained in the Washington Consensus (see Williamson, 1994), which inspired a series of reforms in transition and developing countries. However, the way in which they were interpreted and implemented varied among countries, and a number of critics emerged in search for new ideas (see Stiglitz, 2002; Krueger, 2000; Bhagwati, 2004; Naím, 2000). Consequently, in the late 1990s, a list of the first-generation reforms has been extended with second-generation reforms (i.e. Augmented Washington Consensus), which were by their nature more institutional and focused on the problems of good governance (Rodrik, 2007). The goal of these reforms was to strengthen the state without allowing it to again become bloated (Navia \& Velasco, 2003, p. 270). Therefore, with the development of institutional economics (North, 1990), instead of repeating a specific set of recipes, the focus shifted to the institutional structure in a particular country. Second-generation reforms encompassed broad reforms of the state, the civil service, public service delivery; of the institutions that create and maintain human capital and of the environment in which private firms operate (Navia \& Velasco, 2003, p. 266). In this line of reasoning, they aim at adapting institutional frameworks and regulations for markets to work properly (IMF, 2004 , p. 105). As a result, the political process required by second-generation reforms was more complicated and any reform attempt included a lengthy discussion and participation of all affected parties, whereby achieving a consensus became a sort of norm (Navia \& Velasco, 2003; Krueger, 2000). 
DRUŠ. ISTRAŽ. ZAGREB GOD. 30 (2021), BR. 4, STR. 675-698

VUČKOVIĆ, V., ŠIMIĆ BANOVIĆ, R.:

WHO AND WHAT...
Besides providing the appropriate definition of reforms, measuring progress in reform implementation additionally contributes to the complexity of this research area. There have been various attempts from international organisations and individual researchers to quantify the indicators which can measure or estimate reform effects across countries and/ or through a specific period of time, and changes in such indicators are then considered as reforms (e.g., EBRD Transition Indicators, World Bank Doing Business, OECD Product Market Regulation Index, Heritage Foundation Index of Economic Freedom). In this paper, we follow the ex post approach to the reform analysis which consists of measuring the existing distortions associated with the government policies through various indicators. Reforms are in this case captured as the change in the level of such indicators (see Buti et al., 2010, pp. 12-13).

\section{THE POLITICAL ECONOMY OF STRUCTURAL REFORMS - THEORETICAL AND EMPIRICAL BACKGROUND OF THE SELECTED DETERMINANTS FOR ANALYSING REFORMS IN CROATIA}

From the perspective of political economy, reforms are determined by the interaction between policymakers' reform objectives and a set of economic and political constraints that are not directly under their control (IMF, 2004, p. 109). Therefore, in order to debate on any potential effects of reforms on economic performance, it is necessary to identify factors that affect their implementation. In literature, there are four clusters of hypotheses relevant for reforms - (1) the overall economic conditions, (2) political conditions, (3) internal organisation aspects of policy making and (4) the nature of the reform and communication strategy (Heinemann \& Tanz, 2008). In this paper the focus is on the first two clusters - economic and political.

\section{Economic conditions}

An economic factor with a significant effect on reforms are economic crises. Krueger $(1995$, p. 125) points out that the objective economic situation in a country can be viewed as the demand for reforms where this demand is smaller under favourable economic conditions. Thus, the economic crises may encourage reforms since the economic downturn suggests that existing policies are no longer sustainable. This is the case in countries where economic problems reflect political inertia in decision making (see Krueger, 1995, p. 125). In this way, the crises introduce the element of urgency in the policy-making process, weaken resistance to reforms and increase the cost of reform failure (Lora, 2000; Drazen \& Easterly, 2001; Alesina et al., 2006; Høj et al., 2006). Numerous econometric studies have confirmed that periods of slow economic growth (or its decline) and high unemployment rates are the major deter- 
DRUŠ. ISTRAŽ. ZAGREB GOD. 30 (2021), BR. 4, STR. 675-698

VUČKOVIĆ, V., ŠIMIĆ BANOVIC, R.:

WHO AND WHAT... minants of reforms (Tompson \& Dang, 2010; IMF, 2004; Høj et al., 2006). However, reforms could be easier to implement under favourable macroeconomic conditions considering the window of opportunity when the costs of reforms would be less painful and distributional effects less visible (IMF, 2004, pp. 114-115). Furthermore, international agreements and the establishment of institutions that stimulate reforms through various programmes (e.g. EU SMP) exposing domestic markets to international competition significantly affect the incentives for reforms. Thus, the significance of international influence on reform implementation is also usually tested, since such influence could result in a positive impact on reforms in countries stemming from spill-over or peer-pressure effect.

\section{Political conditions}

In addition to economic factors, the success or failure of reforms is also determined by political factors, i.e. by political institutions which include the rules of the game within which policy making and political processes take place. They provide information, opportunities, incentives, and constraints for citizens and policy makers deciding on their specific strategies (Colomer, 2001, p. 4). Specifically, political institutions have a big role in preserving economic freedom (Holcombe, 2012). In this respect, the institutional characteristics of the decision-making process affect the ability to implement reforms. First, the ideology and political orientation of government determine their position in terms of trade-off between equity and efficiency. For example, the literature shows that left-oriented governments attach more weight to equity, which has a key role in the reform of the labour market (Castanheira et al., 2006). However, even in the case when reforms were to be identical, they would be differently perceived in the eyes of the voters if they were promoted by left- or right-oriented governments (Navia \& Velasco, 2003). In order to capture the ideology effect, the analyses in previous research included a dummy variable that takes the value 1 if reforms are carried out by a left-oriented government and the value 0 in all other cases, and the obtained results mostly show that countries in which the left-oriented party is in power is characterised by smaller reform activity.

Furthermore, the electoral systems could have an indirect effect on reform implementation, stemming from their effects on government fragmentation. For example, the proportional representation (PR) electoral system is associated with a more fragmented party system with frequent coalition governments, while majoritarian electoral systems often result in a single-party government. Therefore, it would be reasonable to expect that these effects are also reflected in the economic policies implemented under different types of party 
DRUŠ. ISTRAŽ. ZAGREB GOD. 30 (2021), BR. 4, STR. 675-698

VUČKOVIĆ, V., ŠIMIĆ BANOVIC, R.:

WHO AND WHAT... systems and governments. Thus, another important political factor that should be taken into consideration is government fragmentation, whereby a larger number of parties leads to a conflict of interest and thus undermines the possibility of forming the pro-reform coalitions. Hence, larger fragmentation makes it more difficult to reach a compromise and increases the instability of the government itself (see Roubini \& Sachs, 1989; Lora, 2000). Furthermore, many analyses also encompass the political competition aspect. Higher political competition is associated with a more efficient government since the ruling party has incentives for better performance. In this case, greater political competition increases the likelihood of successful implementation of reforms, so we can expect a positive sign of the coefficient with the variable. On the other hand, if the probability of re-election is low, politicians can act opportunistically and in this scenario we can expect a decrease in reform activities. As previously stated, the reforms cause larger short-term costs than benefits and policy makers could be punished by voters at the next elections. In this scenario, policy makers are faced with a larger risk of losing office, so their incentives will rather be focused on meeting the short-term interests (see Pavletić, 2010, p. 53). Furthermore, political cycles could also affect the reform process. If the election date is approaching, the government may refrain from implementing unpopular reforms with high short-term costs, while the government, which just came to power, is likely to have an incentive to carry out such reforms (Høj et al., 2006, pp. 100-101). ${ }^{1}$ In addition, at the beginning of the mandate, the political capital would be the largest so this also affects the policy-makers' incentives for their implementation (IMF, 2004).

Besides politicians, there are other agents that have an important role in reform design and implementation. In this paper, we focus on client groups, which are seen as a special type of interest groups connected to various clientelistic arrangements, ${ }^{2}$ but which, unlike typical interest groups, lack the organisational capacity, autonomy and shared preferences to take collective action beyond what their patrons require (Trantidis, 2016). In general, the result of their actions can be corruption and state capture, as well as accommodation of client groups to the disadvantage of public interest. Thus, from the aspect of reform implementation, as the process is faced with the issue of collective action, reforms will not be supported by groups which expect to end up with significant losses, and policy makers have to build coalitions with the groups expecting to obtain significant gains. Within the clientelistic setting, where reforms could bring losses to groups which are part of the incumbent network (Trantidis, 2014), one can expect significant effects on the entire process. Moreover, clientelism can be seen as a powerful tool of political 
DRUŠ. ISTRAŽ. ZAGREB GOD. 30 (2021), BR. 4, STR. 675-698

VUČKOVIĆ, V., ŠIMIĆ BANOVIC, R.:

WHO AND WHAT... mobilisation, resulting in a policy bias in favour of preserving the clientele's supply of benefits (individual and collective). If the patron depends on the support of their clientelistic network, then their ultimate goal when in power is to satisfy demands of the clients (Trantidis, 2016). Reforms which would result in higher costs for clients, thus weakening their alliances with politicians, could represent a big risk for the government. The best example is the public administration reform, because the clientelistic system is seen as highly connected with the inefficiencies and the increasing employment of the public sector (Cruz \& Keefer, 2015; Trantidis, 2016). Various aspects of clientelism and nepotism are encompassed by the concept of the 'economy of favours' (Ledeneva, 1998, $2008,2017)$, which functions on the basis of favours of access and predominantly originates in the redistribution of public resources.

\section{STRUCTURAL REFORMS IN CROATIA}

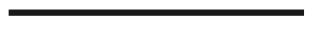

Croatia has achieved the most progress in the first-generation of reforms (especially financial and trade liberalisation encompassed by the Resilient and Integrated dimension in Figure 1).

\section{$\rightarrow$ FIGURE 1 Structural reforms measured by transition scores for six qualities of a sustainable market economy (EBRD Transition Report 2019-2020)}

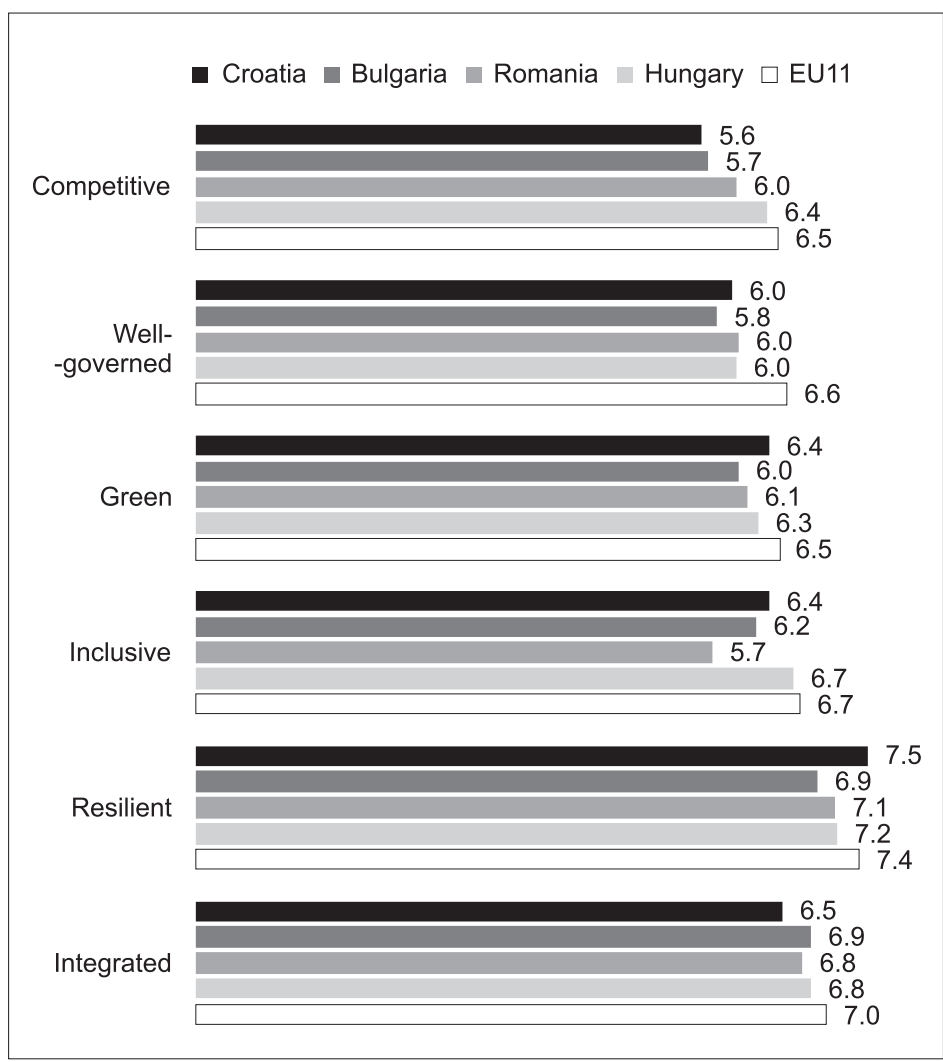

Source: Data extracted from EBRD Transition Qualities (2019) 
DRUŠ. ISTRAŽ. ZAGREB GOD. 30 (2021), BR. 4, STR. 675-698

VUČKOVIĆ, V., ŠIMIĆ BANOVIC, R.:

WHO AND WHAT... $\rightarrow$ FIGURE 2

Product Market Regulation 2013
Specifically, the liberalisation of international trade was a priority among the market reforms in Croatia, and gradually took place through several phases: membership in the World Trade Organisation (WTO), the Stabilisation and Association Agreement with the EU, the EU membership negotiations, and through full membership in the EU (Goldner Lang \& Perišin, 2011). However, Croatia constantly lags in the area of second-generation reforms' implementation. The lowest level of progress was achieved within the regulatory dimension that affects the incentives of economic agents, i.e. in the Competitive and Well-governed area, especially relative to the EU11 average.

The same can be concluded when analysing the OECD data on the Product Market Regulation index. Namely, Croatia performs the worst among the NMS (Figure 2). De Rosa et al. (2009) calculated the PMR index for 2007 and the obtained value of index in that year was 2.0. Thus, relative to 2007, in 2013, the PMR value for Croatia increased, implying that the regulatory environment in Croatia became even more restrictive.

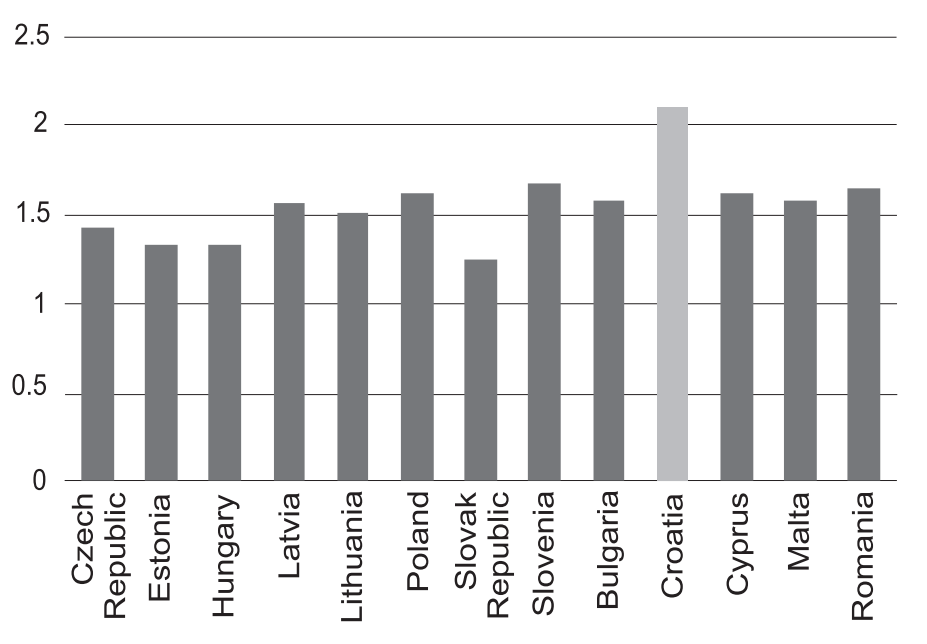

Source: Data extracted from OECD PMR database

Although the most used measure for structural reforms in the literature is the OECD's PMR index, we cannot use it in our analysis since Croatia is included in the database only for the year 2013. Therefore, we focus on the Heritage Foundation database that covers a longer time period but also highlights the shortcomings of the regulatory environment encompassed by the PMR index. Figure 3 shows the data for individual pillars contained within the aggregate values of Index of Economic Freedom, which are grouped into four broad categories of economic freedom: the rule of law, government size, regulatory efficiency and open markets. 


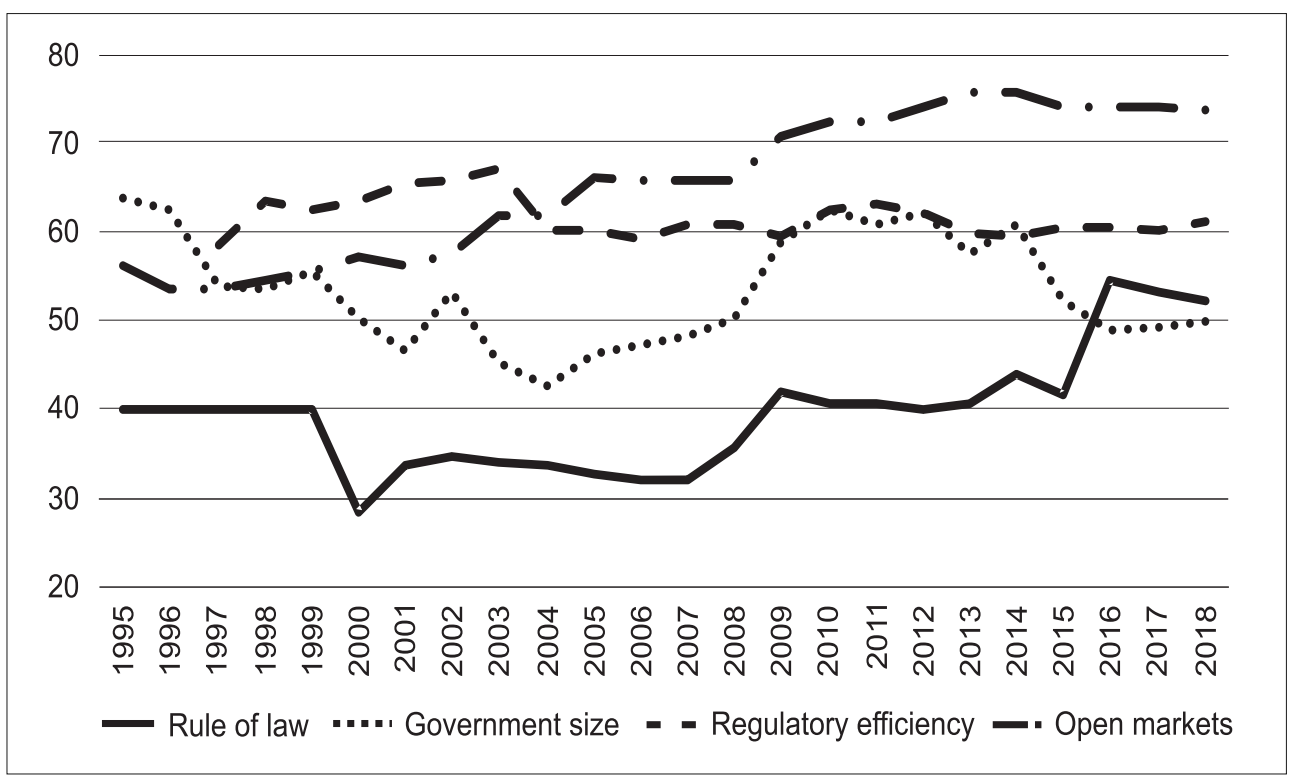

Source: Data extracted from The Heritage Foundation database (2019)

i FIGURE 3

Economic Freedoms by categories

(1997-2018)

\section{P FIGURE 4}

Top five components with worst performance in the Institutions pillar $(0-100)$
Data presented in Figure 3 suggest that the worst performance is found in the Rule of law dimension. Also, if the change in each category is compared to 1996, it is rather evident that Regulatory efficiency has experienced the lowest progress (from 58.4 to 61.1, respectively). Yet another source, Global Competitiveness Index (WEF, 2018), shows that the main problems in Croatia can continuously be found in the institutions pillar, precisely in judicial independence, efficiency of legal framework in challenging regulations, burden of government regulation, efficiency of legal framework in settling disputes and future orientation of government (Figure 4). Also, these areas record the lowest score, and are also deteriorating relative to previous reports.

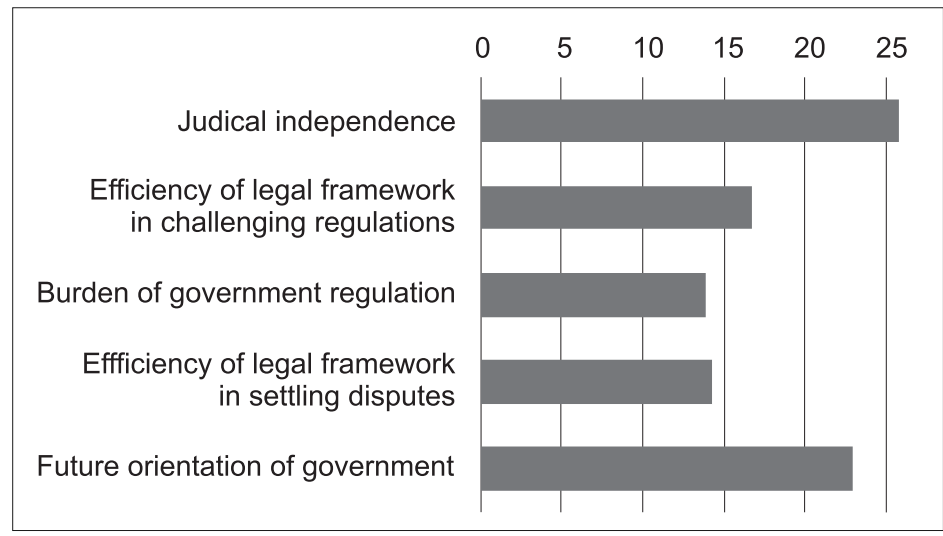


DRUŠ. ISTRAŽ. ZAGREB GOD. 30 (2021), BR. 4, STR. 675-698

VUČKOVIĆ, V., ŠIMIĆ BANOVIC, R.:

WHO AND WHAT...
FIGURE 5

Reform Index (2006-2015)
Taking into consideration all things mentioned above, the main question remains: Why have the reforms in these areas not been implemented despite the fact that they would exert a positive effect on the overall economic performance? A recent research on the measurement of reform implementation, which included Croatia, Meunier and Zaman (2015), quantified the overall progress of reforms in five different areas (labour market, business environment, public finance, social policy and public administration) through a composite indicator. As it can be seen in Figure 5, the calculated Reform Index values for Croatia indicate that the highest index value was achieved in 2013 (the year of EU accession), followed by a slight decrease, confirming the strong international influence on reform implementation.

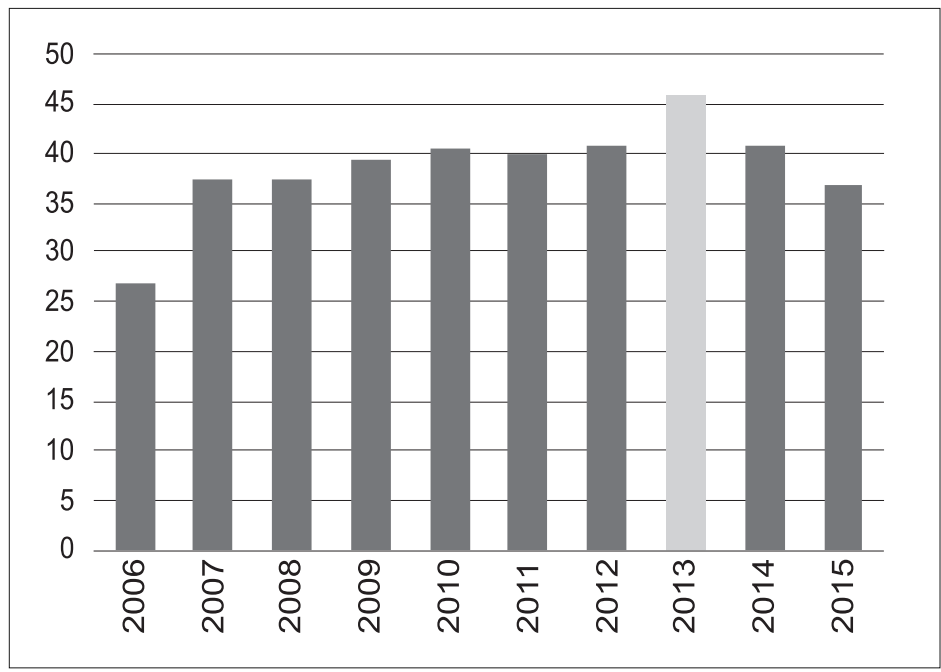

Source: Meunier and Zaman (2015, p. 9)

Finally, Meunier and Zaman $(2015$, p. 9) concluded that a decline in the reform index after 2013 was mainly driven by the increase in corruption. Their conclusion highlights even more the need for a detailed analysis of factors behind the reform process in Croatia.

\section{The choice and descriptive analysis of the variables}

Following the approach applied in previous studies (e.g., Høj et al., 2006; Belke et al., 2006) for a construction of dependent (reform) variables, we use data from the Index of Economic Freedom series of reports, which includes changes from a high degree of state intervention and protectionism towards efficiency, better market functioning and reduced state interventions. In this way, the index used in the analysis covers both the economic liberalisation and governance aspects of structural reforms. This index, as well as other composite indices 
DRUŠ. ISTRAŽ. ZAGREB GOD. 30 (2021), BR. 4, STR. 675-698

VUČKOVIĆ, V., ŠIMIĆ BANOVIC, R.:

WHO AND WHAT..
(1) TABLE 1

Independent variables and expected effect on reforms measuring economic freedom which are used as a proxy for reforms, is faced with significant critiques. In the critical survey of recent evidence on the effect of market-oriented institutions and policies on economic growth, focusing specifically on studies using the economic freedom indicator of the Fraser Institute, de Haan et al. (2006) stress several issues related to the use of such indices, e.g., heterogeneity, subjectivity and aggregation procedure. However, the index is broadly used as a proxy measure for reforms. ${ }^{3}$ Finally, as the goal of this paper is not to assess the normative aspects of specific values of this index nor the desirable degree of economic freedom, we just record a reform as a positive change in the index. We estimate the multiple linear regression model in the following form:

$$
\begin{aligned}
& \text { REFORM }= \\
& =\beta_{1}+\beta_{2} \text { GDPgrowth }+\beta_{3} \text { ELECTIONS }+\beta_{4} \text { GOV }_{\text {FRAGMENTATION }}+ \\
& \beta_{5} \text { CLIENTELISM }+\beta_{6} \text { CORRUPTION }+\beta_{7} \text { EU }+e
\end{aligned}
$$

We proceed with the discussion on the trends in economic and political indicators specifically selected as independent variables for the analysis in this paper, the list of which is

\begin{tabular}{|c|c|c|c|}
\hline Variable & Description & $\begin{array}{l}\text { Expected } \\
\text { effect }\end{array}$ & Source \\
\hline GDP growth & $\begin{array}{l}\text { Captures the effect of } \\
\text { economic conditions }\end{array}$ & $+/-$ & World Economic Outlook (WEO, IMF) \\
\hline Elections & $\begin{array}{l}\text { Political cycles } \\
(\mathrm{L}=2 ; \mathrm{F}=1)\end{array}$ & $+/-$ & $\begin{array}{l}\text { Database of Political Institutions (DPI), } \\
\text { World bank (2019) }\end{array}$ \\
\hline herfgov & $\begin{array}{l}\text { Government } \\
\text { fragmentation }\end{array}$ & + & $\begin{array}{l}\text { Database of Political Institutions (DPI), } \\
\text { World Bank (2019) }\end{array}$ \\
\hline Clientelism & Clientelism index & - & $\begin{array}{l}\text { Varieties of Democracy (V-Dem) } \\
\text { Project: https://doi.org/10.23696/vdemds20 }\end{array}$ \\
\hline Corruption & Political corruption & - & $\begin{array}{l}\text { Varieties of Democracy (V-Dem) } \\
\text { Project: https://doi.org/10.23696/vdemds20 }\end{array}$ \\
\hline EU & $\begin{array}{l}\text { EU membership (value } 1 \\
\text { for years of membership) }\end{array}$ & + & Authors compilation \\
\hline
\end{tabular}
given in Table 1 . The period covered by the analysis is from 1996 to 2017.

As previously described, prevailing empirical literature tests the effect of economic conditions on reform implementation. While some confirm that it is easier to implement reforms during the good times when the cost of reforms are smaller and the distribution effects less visible (IMF, 2004, pp. 114-115), others show that in such a scenario reforms are also easier to delay and that the economic crises introduce a degree of urgency in the process, suppress resistance to reforms 
and increase the cost of their delay (see Lora, 2000; Drazen \& Easterly, 2001; Alessina et al., 2006; Høj et al., 2006; Krueger, 1995).

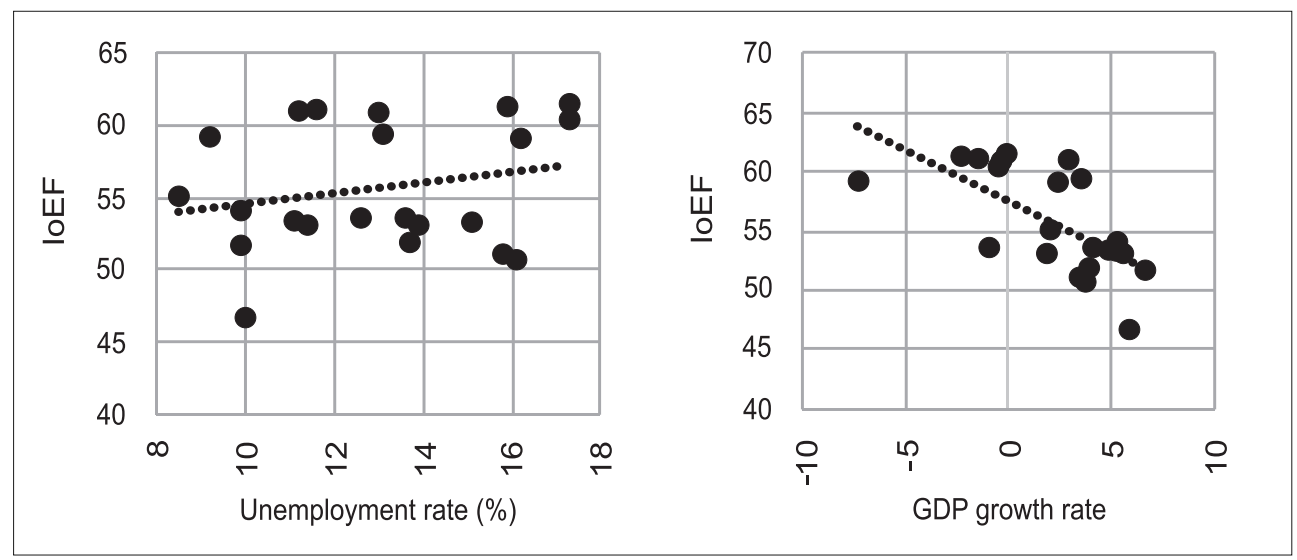

Source: Data extracted from World Economic Outlook database (IMF, 2019) and The Heritage Foundation database (2019)

(1) FIGURE 6 Index of Economic Freedom vs Unemployment rate and GDP growth (1996-2017)
Based on data in Figure 6, we could conclude that reforms were not implemented during the periods of economic growth, i.e. that economic downturn is a significant factor that leads to reforms. Thus, although reform implementation would be cost-saving and easier under favourable economic conditions, in Croatia it was more attractive to delay reforms and preserve the status quo during good times with the primary goal of remaining in power. Franičević (2004, p. 269) calls this scenario a paradox that leads to the second-best solution. However, since there are a large number of factors that could also potentially affect reform implementation, during both the good and the bad times, this conclusion is only intuitive and is further econometrically tested along with the following dimensions of political institutions in the model: government fragmentation, political cycles, clientelism and corruption.

First, since the reform which introduced the proportional representation (PR) electoral system in 2000 increased the frequency of coalition governments, which are according to theoretical assumptions less likely to implement reforms (see Roubini \& Sachs, 1989; Persson \& Tabellini, 2003), we include the indicator on government fragmentation in our analysis. Precisely, within coalition governments, each of the coalition partners will try to satisfy the demands of their electorate or their own opportunistic interests. Therefore, we examine the government fragmentation measured by the Herfindahl index (herfgov), which represents a measure of concentration of the ruling coalition. In the case of a single-party government, the index equals 1, while in the case of a coalition government, it takes a value between 0 and 1 . Thus, the higher the 
DRUŠ. ISTRAŽ. ZAGREB GOD. 30 (2021), BR. 4, STR. 675-698

VUČKOVIĆ, V., ŠIMIĆ BANOVIC, R.:

WHO AND WHAT...

(1) FIGURE 7

Government fragmentation in

Croatia (1996-2017) number of parties in the coalition government, the lower the value of the Herfindahl index. We expect this variable to have a negative impact on reforms as more fragmented governments (the lower index) possess less power to implement them. That is, an increase in the value of herfgov (i.e., the decrease of the number of parties in the coalition) results in larger reform implementation. Therefore, we expect a positive sign of the coefficient with this variable in the model. The advantage of this index is that it does not only measure the number of parties but also their parliamentary size. Data for fragmentation comes from Database of political institutions (World Bank, 2019) and is shown in Figure 7.

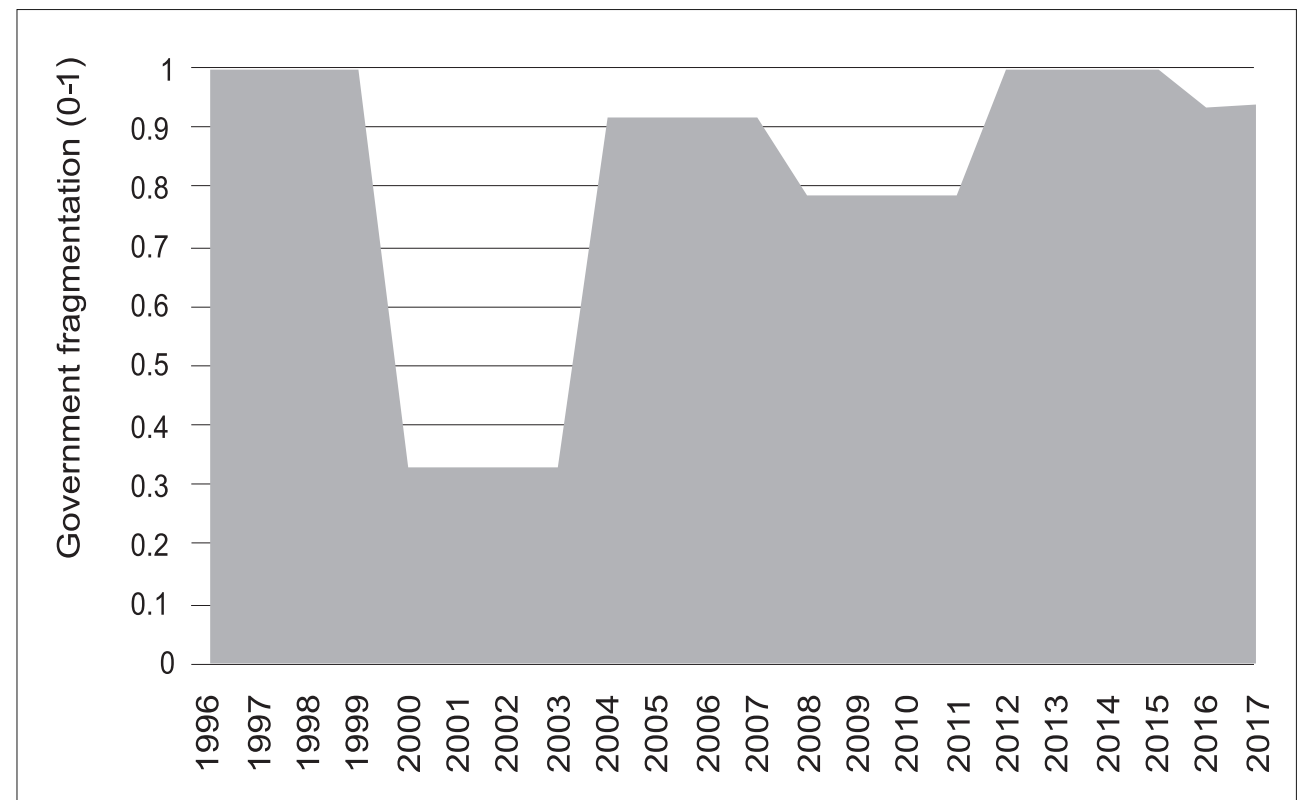

Source: Data extracted from World Bank (2019)

The proportional representation (PR) electoral systems, which increased the frequency of coalition governments and government fragmentation as shown in Figure 7, could also result in reduced responsibility of politicians to the electorate, free-riding problems, rent-seeking and increased corruption (Voigt, 2009; Persson \& Tabellini, 2003). Indeed, corruption is severely hindering the policy-making process in Croatia, as well as the development of the private sector, as it can be found in international benchmarks and reports such as the World Bank Enterprise Surveys, Doing Business series of reports and WEFs Global Competitiveness Reports.

In general, in the post-socialist context, three rent-seeking mechanisms could be distinguished: market capture by political elites; state capture by business elites; and capture of 
DRUŠ. ISTRAŽ. ZAGREB GOD. 30 (2021), BR. 4, STR. 675-698

VUČKOVIĆ, V., ŠIMIĆ BANOVIC, R.:

WHO AND WHAT... oligarchs by autocratic rulers (Mihályi \& Szelényi, 2019). The first mechanism includes the following: the former communist elite converting its political power into private wealth; market capture by new political elites during privatisation aimed at increasing personal wealth or client recruitment; and manipulation of market processes for the purpose of personal enrichment or client recruitment (Mihályi \& Szelényi, 2019). The afore-mentioned mechanism was rather present in the initial post-socialist period and as such particularly manifested through the privatisation process (Račić \& Cvijanović, 2004). It contributed to the transformation of Croatian political capitalism towards specific clientelist capitalism with its current features (Cvijanović \& Redžepagić, 2011). Pejovich (2018) argues that rent-seeking plays an inevitable role in the rise of liberal socialism ${ }^{4}$ in the 2000s. He claims that redistributive policies (and governmental control over the resources) replace competitive markets and that that process is encouraged by political support. In other words, 'the rule by law leads to a cultural change: from working for a living, to voting for a living' (Pejovich, 2018, p. 121)

Croatia is considered a crony capitalist country (Ivanković, 2017; Šimić Banović, 2019) and crony capitalism is a type of rent-seeking society whose dominant attribute is that its rent-seeking structure is effectively justified by populist discourse (Aligica \& Tarko, 2014). Kotarski and Petak (2019, p. 17) stress 'huge rent-seeking costs of institutionalised arrangements characteristic of a captured state' in Croatia. Also, research on Croatia (Šimić Banović, 2019) supports Alesina and Giuliano's (2015) claim on the culture and formal institutions evolving and interacting with a continuous feedback effect. That feedback effect in Croatia is rather obvious in the formalisation of clientelistic and nepotistic arrangements in Croatian public sector bodies (Šimić Banović, 2019) as well as among interest groups (Vidačak \& Kotarski, 2019). Overall, according to Petak and Kotarski (2019), the Croatian case undoubtedly illustrates weakened institutional development being strongly intertwined with vested interests. Another practice illustrating 'economy of favours' and clientelism in Croatia is uhljeb. An uhljeb is best described as a public sector employee whose decisive 'competence' is a nepotistic relationship or political party affiliation. In any available occasion, uhljeb returns the favour(s) and consequently, contributes to the multiplication of uhljebs. In addition, an uhljeb can also be an entrepreneur who, using his personal contacts and not market criteria, sells overpriced goods or services to the public administration bodies or state-owned enterprises (Šimić Banović, 2019). 
DRUŠ. ISTRAŽ. ZAGREB GOD. 30 (2021), BR. 4, STR. 675-698

VUČKOVIĆ, V., ŠIMIĆ BANOVIC, R.:

WHO AND WHAT...
P FIGURE 8

Clientelism index (average values for the 1996-2018 period)
During the 1990s' lost decade, Croatia had an autocratic and populist government that mixed clientelism and limited pluralism, and within such a setting (characterised by the absence of veto actors), the single-party (HDZ) government was able to sustain discriminatory policies that unevenly allocated losses and gains (Guardiancich, 2013, p. 36). After the 2000 election reform, and the change in government, the endemic nature of Croatian clientelism further hindered the implementation of sound policies, which resulted in the collapse of a fragile six-party coalition and an early return to power of HDZ in 2003 (Guardiancich, 2013, p. 41). To underline, Croatia's case is in line with the 'economy of favours' concept presented by Ledeneva (1998, 2008,2018 ). The (mis)use of public resources for private gains is largely tolerated. In line with the authors' research of informal exchange and networks in certain societies (Choi \& Storr, 2019), loyalty and network affiliation play a greater role than meritocracy, and the informal exchange is executed at the third parties' expense. Consequently, Croatian clientelism can be labelled as relational rather than electoral. According to Gans-More et al. (2014), relational clientelism is more efficient (for the parties involved), more resilient and plays a long-term role and effect in the society.

Clientelism index used as a variable in our model comes from the Varieties of Democracy (V-Dem) Project and includes three aspects of the clientelistic setting: (1) vote-buying, (2) whether party linkages are programmatic or clientelistic and (3) nature of government spending (particularistic vs. public goods). ${ }^{5}$ The lower index scores indicate a normatively better situation (less clientelism) and higher scores a normatively worse situation (more clientelism) (Coppedge et al., 2020). Figure 8 shows the clientelism index for Croatia relative to the comparable NMS and EU average. We can see that Croatia is among the top four worst performers, along with Bulgaria, Romania and Hungary.

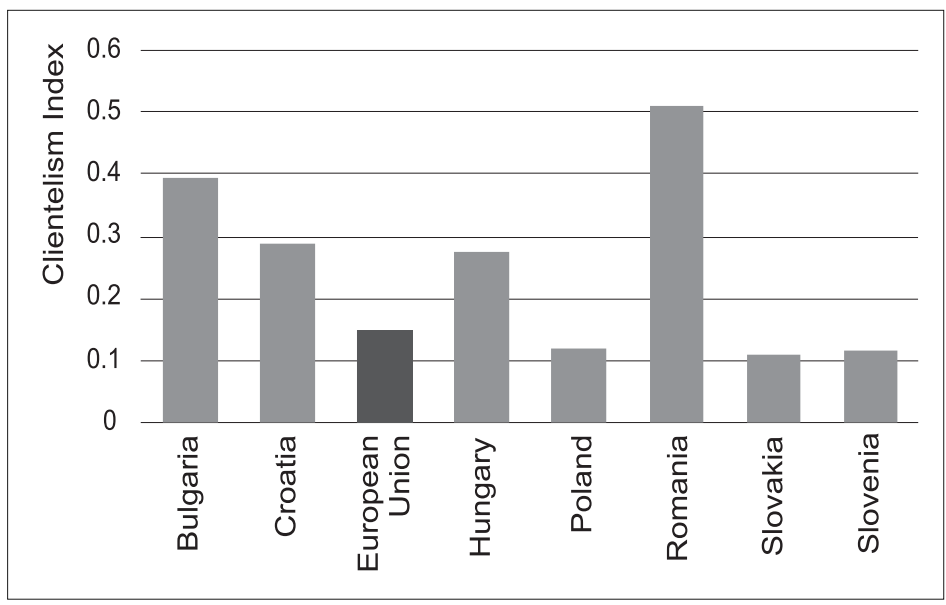

Source: Data extracted from V-DEM project database 
DRUŠ. ISTRAŽ. ZAGREB

GOD. 30 (2021), BR. 4, STR. 675-698

VUČKOVIĆ, V., ŠIMIĆ BANOVIC, R.:

WHO AND WHAT...
We also include corruption in the model, which serves as a control variable and a robustness check since some forms of clientelism can be corrupt in themselves, and clientelism may generate incentives for other corrupt behaviours by influencing the need for funds to maintain clientelistic machines (Singer, 2009). More precisely, we use Political corruption index, which measures six types of corruption distinguishing between executive, legislative and judicial corruption: petty and grand; bribery and theft; corruption influencing law making and that affecting implementation. The index runs from 0 to 1, i.e., from less to more corruption (V-DEM Project, 2019).

Finally, as already mentioned, international institutions had an important role in the economic policy in Croatia regardless of the ideology of government, especially the IMF and the World Bank. The processes of internationalisation and globalisation in Croatia were also significantly shaped by the country's European perspective. Specifically, the process of EU accession had direct and indirect effects on the choice of the specific policies and reform programmes. More precisely, the direct effects refer to effects that arise from meeting the criteria for joining the EU, while indirect effects arise from changes in the ideological position of the ruling parties (Lolos, 2005, pp. 82-83). Croatian EU membership is included in the analysis through a dummy variable.

\section{The results of econometric analysis}

The results of the multiple regression model are presented in Table 2. The results show that the implementation of reforms in Croatia is significantly affected by the GDP growth rate, clientelism, government fragmentation, political corruption and electoral cycles. The variable capturing international influence through EU membership, although with expected sign, does not show to be statistically significant.

The results can be summed up into the following findings: (1) reforms are implemented during the economic downturn, (2) clientelism makes reforms harder to implement, (3) increase (decrease) in government fragmentation has a negative (positive) effect on reform implementation and (4) politicians start to decrease their reform activity prior to elections. The corruption variable is statistically significant at the 5\% significance level, and has a negative sign, implying that an increase in corruption index hinders reform activity. In the second model, when the corruption variable is dropped out, our clientelism variable is still statistically significant and has the same negative sign. The validity of the model was also tested. Global F test $(P$-value $<0.0001)$ indicates that the model is significant for predicting reforms based on selected independent variables in the model. Also, the value of $R$-square is 
DRUŠ. ISTRAŽ. ZAGREB GOD. 30 (2021), BR. 4, STR. 675-698

VUČKOVIĆ, V., ŠIMIĆ BANOVIC, R.:

WHO AND WHAT...

TABLE 2

Results of the multiple regression model
0.93, which means approximately $93 \%$ of the variation in the dependent variable is explained by the independent variables. Based on the post-estimation results for Engle's Lagrange multiplier (LM) test for the presence of autoregressive conditional heteroscedasticity (with prob $>$ chi2 0.68 ) and Durbin's alternative test for serial correlation in the disturbance (with prob > F 0.32), we conclude that the errors are not autoregressive conditional heteroscedastic and that there is no serial correlation in the errors, respectively.

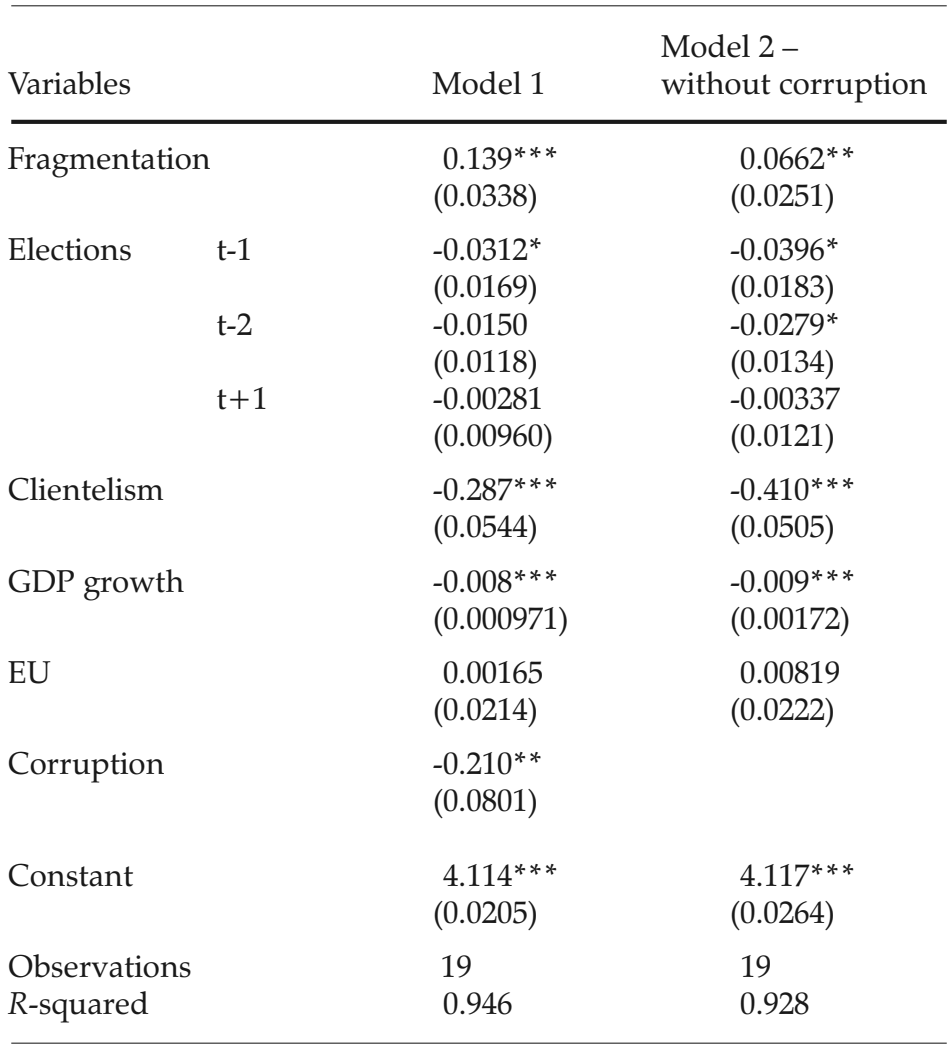

Robust standard errors in parentheses

${ }^{* * *} p<0.01,{ }^{* *} p<0.05,{ }^{*} p<0.1$

\section{CONCLUSION}

For many years now, various international benchmarks and relevant progress reports have been warning about the deficits of reform implementation in Croatia. Croatia is among the least developed EU countries, yet it does not really show the signs of persistent, coherent and radical changes. This research presents the indicators and trends related to reform implementation. Moreover, it focuses on the barriers that hinder structural reforms. The results show that the implementation of reforms in Croatia is significantly affected by GDP 
DRUŠ. ISTRAŽ. ZAGREB GOD. 30 (2021), BR. 4, STR. 675-698

VUČKOVIĆ, V., ŠIMIĆ BANOVIĆ, R.:

WHO AND WHAT... growth rate, clientelism, government fragmentation, corruption and electoral cycles. Reforms are implemented during the economic downturn, clientelism and corruption make reforms harder to implement, increase in government fragmentation has a negative effect on reform implementation and politicians start to decrease their reform activity prior to elections. We can conclude that the Croatian political system limits the incentives of politicians for the implementation of the reforms. The pronounced frequency of coalition governments can result in opportunistic behaviour of politicians who follow their own interests and/or the interests of their electorate, difficulties in reaching a consensus and in the common pool problem. That environment makes a fertile soil for relational clientelism that shows to be more long-term, rather resilient and more difficult to eradicate than electoral ('one off') clientelism. Furthermore, the tolerance of and the development of 'economy of favours' contributes to a vicious circle of clientelism and other corrosive informal practices in Croatian society. Still, as recognised by burgeoning literature sources, those practices may clearly indicate the deficits of the formal system - as thoroughly disentangled in this paper. Due to similar legacy, this research is expected to have broader resonance for European post-socialist countries, particularly the ones with similar political systems.

Future research should question whether the Croatian governments have so far been oriented towards the increase in government revenues and maximisation of their chances for winning the elections, or increasing the benefits for the business sector. All these questions could be linked to the findings from the analysis performed in this paper. Attention should be paid to the finding that the status quo was maintained in periods of economic growth, which is a further reflection of the opportunistic behaviour of key actors and short-term interests of the politically influential individuals or interest groups. Finally, one of the future venues for the research should include the special position of various interest groups which favour their status in the reform process. Such an approach requires the analysis of specific reform areas, e.g., the pension system, labour market, health care, business environment etc.

\section{NOTES}

${ }^{1}$ On the other hand, the government might have larger incentives to implement popular reforms before elections in order to increase their chances of winning.

${ }^{2}$ According to Robinson and Verdier (2013, p. 262), a most common example of such arrangements is the situation when jobs are exchanged for votes. 
DRUŠ. ISTRAŽ. ZAGREB GOD. 30 (2021), BR. 4, STR. 675-698

VUČKOVIĆ, V., ŠIMIĆ BANOVIC, R.

WHO AND WHAT...
${ }^{3}$ For a detailed description of studies using various reform measures, including the Index of Economic Freedom see Campos et al. (2017).

${ }^{4}$ According to Pejovich (2018), 'liberal socialism', has one critical difference when compared with its predecessors, i.e., 'unlike all three types of socialism in the last century - Fascism, National Socialism and Communism - liberal socialism is not imposed from the top down; it is emerging from the bottom up'.

${ }^{5}$ The relative value of particularistic (targeted on a specific corporation, sector, social group, region, party, or set of constituents; may be referred to as "pork", "clientelistic", or "private goods") and public-goods (intended to benefit all communities within a society) spending.

\section{ACKNOWLEDGEMENT}

The authors would like to thank Prof Steve Pejovich for his useful and (as always) thought-provoking comments, as well as to two anonymous reviewers.

Also, we would like to thank to all the participants of conference "Clientelism in Croatia: policies, procedures and consequences of trading with institutional power" organized by the Centre for Democracy and Law Miko Tripalo in February 2019, where a first draft of the paper was presented.

\section{REFERENCES}

Alesina, A., \& Giuliano, P. (2015). Culture and institutions. Journal of Economic Literature, 53(4), 898-944. https://doi.org/10.1257/jel.53.4.898 Alesina, A., Ardagna, S., \& Trebbi, F. (2006). Who adjusts and when? On the political economy of reforms. IMF Staff Papers, Vol. 53, Special Issue. https://doi.org/10.3386/w12049

Aligica, P. D., \& Tarko, V. (2014). Crony capitalism: Rent seeking, institutions and ideology. Kyklos, 67(2), 156-176. https://doi.org/10.1111/ kykl.12048

Bartlett, W. (2008). Europe's troubled region. Economic development, institutional reform and social welfare in the Western Balkans. Routledge. https://doi.org/10.4324/9780203644898

Belke, A., Herz, B., \& Vogel, L. (2006). Exchange rate regimes and reforms: A panel analysis for the world versus OECD countries. International Finance, 9(3), 317-342. https://doi.org/10.1111/j.1468-2362.2006. 00184.x

Bhagwati, J. (2004). In defense of globalization. Oxford University Press. Buti, M., Turrini, A., Van den Noord, P., \& Biroli, P. (2010). Reforms and re-elections in OECD countries. Economic Policy, 25(61), 61-116. https://doi.org/10.1111/j.1468-0327.2009.00237.x

Campos, N. F., De Grauwe, P., \& Ji, Y. (2017). The political economy of structural reforms in Europe. Oxford. https://doi.org/10.1093/oso/97801 98821878.001.0001

Castanheira, M., Galasso, V., Carcillo, S., Nicoletti, G., Perotti, E., \& Tsyganok, L. (2006). How to gain political support for reforms. Structural Reforms Without Prejudices. Oxford University Press. 
DRUŠ. ISTRAŽ. ZAGREB GOD. 30 (2021), BR. 4, STR. 675-698

VUČKOVIĆ, V., ŠIMIĆ BANOVIC, R.:

WHO AND WHAT...
Choi, S. G., \& Storr, V. H. (2019). A culture of rent seeking. Public Choice, 181(1-2), 101-126. https://doi.org/10.1007/s11127-018-0557-x

Colomer, J. M. (2001). Political institutions: Democracy and social choice. Oxford University Press. https://doi.org/10.1093/019924183X.001.0001

Coppedge, M., Gerring, J., Knutsen, C. H., Lindberg, S. I., Teorell, J., Altman, D., Bernhard, M., Fish, M. S., Glynn, A., Hicken, A., Lührmann, A., Marquardt, K. L., McMann, K., Paxton, P., Pemstein, D., Seim, B., Sigman, R., Skaaning, S. E., Staton, J., Cornell, A., Gastaldi, L., Gjerløw, H., Mechkova, V., von Römer, J., Sundtröm, A., Tzelgov, E., Uberti, L., Wang, Y. T., Wig, T., \& Ziblatt, D. (2020). "V-Dem Codebook v10". Varieties of Democracy (V-Dem) Project. https://doi.org/10.23696/vdemds20

Cruz, C., \& Keefer, P. (2015). Political parties, clientelism, and bureaucratic reform. IDB Publications (Working Papers) 6968, Inter-American Development Bank. https://doi.org/10.18235/0000024

Cvijanović, V., \& Redžepagić, D. (2011). From political capitalism to clientelist capitalism? The case of Croatia. Zbornik radova Ekonomskog fakulteta u Rijeci: časopis za ekonomsku teoriju i praksu, 29(2), 355-372.

De Haan, J., Lundström, S., \& Sturm, J.-E. (2006). Market-oriented institutions and policies and economic growth: A critical survey. Journal of Economic Surveys, 20(2), 157-191. https://doi.org/10.1111/ j.0950-0804.2006.00278.x

de Rosa, D., Madzarevic-Sujster, S., Boromisa, A., \& Sonje, V. (2009). Barriers to competition in Croatia: The role of government regulation. World Bank. https://doi.org/10.1596/1813-9450-5100

Drazen, A., \& Easterly, W. (2001). Do crises induce reform? Simple empirical tests of conventional wisdom. Economics and Politics, 13(2), 129-157. https://doi.org/10.1111/1468-0343.00087

EBRD (2019). Transition qualities indicators. https://www.ebrd.com/ economic-research-and-data/transition-qualities-asses.html

EC - European Commission (2019). Country Report Croatia 2019 Including an In-Depth Review on the prevention and correction of macroeconomic imbalances. Brussels, 27. February 2019. https://ec.europa.eu/info/ sites/info/files/file_import/2019-european-semester-country-reportcroatia_en.pdf

Franičević, V. (2004). Deficiti i izazovi postsocijalističke transformacije $\mathrm{u}$ Hrvatskoj [Deficits and challenges of post-socialist transformation in Croatia]. In J. Kregar, V. Puljiz, \& S. Ravlić (Eds.), Hrvatska - kako dalje: Zadanosti i mogućnosti [Croatia - how to proceed: Tasks and opportunities] (pp. 263-282). Pravni fakultet Sveučilišta u Zagrebu, Centar za demokraciju Miko Tripalo.

Gans-Morse, J., Mazzuca, S., \& Nichter, S. (2014). Varieties of clientelism: Machine politics during elections. American Journal of Political Science, 58(2), 415-432. https://doi.org/10.1111/ajps.12058

Goldner Lang, I., \& Perišin, T. (2011). Postupna liberalizacija kretanja roba i ljudi u Hrvatskoj i Makedoniji - prije i nakon članstva u EU [Gradual liberalization of the movement of goods and people in Croatia and Macedonia - before and after EU membership]. Zbornik Pravnog fakulteta u Zagrebu, 61(2), 613-642. 
DRUŠ. ISTRAŽ. ZAGREB GOD. 30 (2021), BR. 4, STR. 675-698

VUČKOVIĆ, V., ŠIMIĆ BANOVIC, R. WHO AND WHAT..
Guardiancich, I. (2013). Pension reforms in Central, Eastern and Southeastern Europe. From post-socialist transition to the global financial crisis. Routledge. https://doi.org/10.4324/9780203098196

Heinemann, F., \& Tanz, B. (2008). The impact of trust on reforms. Journal of Economic Policy Reform, 11(3), 173-185. https://doi.org/10.1080/ 17487870802405375

Holcombe, R. G. (2012). Democracy and prosperity. In Y. B. Choi (Ed.), Institutional economics and national competitiveness (pp. 1-24). Routledge.

Høj, J., Galasso, V., Nicoletti, G., \& Dang, T. T. (2006). The political economy of structural reform: Empirical evidence from OECD countries. OECD Economics Department Working Papers, No. 501.

IMF (2019). World Economic Outlook database. https://www.imf.org/en/ Publications/WEO/weo-database/2019/October

IMF (2004). Fostering structural reforms in industrial countries. World Economic Outlook. Advancing Structural Reforms, 103-146.

Ivanković, Ž. (2017). The political economy of Crony capitalism: A case study of the collapse of the largest Croatian conglomerate. Croatian Political Science Review, 54(4), 40-60.

Kotarski, K., \& Petak, Z. (2019). Croatia's post-communist transition experience: The paradox of initial advantage turning into a middle-income trap. In Z. Petak \& K. Kotarski (Eds.), Policy-making at the European periphery: The case of Croatia. New Perspectives on South-East Europe (pp. 1-20). Palgrave MacMillan. https://doi.org/10.1007/978-3319-73582-5

Kouamé, W. A., \& Tapsoba, S. J. (2018). Structural reforms and firms' productivity: Evidence from developing countries. Working paper 216, Development Policies. https://hal.archives-ouvertes.fr/hal-01723100/file/ P216-Ferdi-Kouamé\%20and\%20Tapsoba.pdf

Krueger, A. O. (1995). Political economy of policy reform in developing countries. The MIT Press.

Krueger, A. O. (Ed.) (2000). Economic policy reform: The second stage. University of Chicago Press.

Ledeneva, A. (1998). Russia's economy of favours: Blat, networking, and informal exchange. Cambridge University Press.

Ledeneva, A. (2008). Blat and Guanxi: Informal practices in Russia and China. Comparative Studies in Society and History, 50(1), 118-144. https://doi.org/10.1017/S0010417508000078

Ledeneva, A. (2017). The ambivalence of favour: Paradoxes of Russia's economy of favours. In D. Henig \& N. Makovicky (Eds.), Economies of favour after socialism (pp. 21-49). Oxford University Press. https://doi.org/10.1093/acprof:oso/9780199687411.003.0002

Ledeneva, A. (2018). Introduction: The informal view of the world key challenges and main findings of the Global Informality Project. In A. Ledeneva (Ed.), The global encyclopaedia of informality: Understanding social and cultural complexity (Volume 1, pp. 1-27). UCL Press. https://doi.org/10.2307/j.ctt20krxh9.8

Lolos, S. E. G. (2005). The role of European integration in the reform process: The Greek experience. In M. Ludahl \& M. L. Wyzan (Eds.), Political economy of reform failure (pp. 86-104). Routledge. 
DRUŠ. ISTRAŽ. ZAGREB GOD. 30 (2021), BR. 4, STR. 675-698

VUČKOVIĆ, V., ŠIMIĆ BANOVIĆ, R.:

WHO AND WHAT...
Lora, E. (2000). What makes reforms likely? Timing and sequencing of structural reforms in Latin America. Working paper 424, Inter-American Development Bank. Washington, D.C. https://doi.org/10.2139/ ssrn. 1817223

Meunier, B., \& Zaman, C. (2015). A proposed index for measuring the implementation of reforms. SSRN 2698297. https://doi.org/10.2139/ssrn. 2698297

Mihályi, P., \& Szelényi, I. (2019). The place of rent-seeking and corruption in varieties of capitalism models. In T. Gerőcs \& M. Szanyi (Eds.), Market liberalism and economic patriotism in the capitalist world-system. International political economy series (pp. 67-97). Palgrave Macmillan. https://doi.org/10.1007/978-3-030-05186-0_5

Naim, M. (2000). Fads and fashion in economic reforms: Washington consensus or Washington confusion? Third World Quarterly, 21(3), 505-528. https://doi.org/10.1080/01436590050057753

Navia, P., \& Velasco, A. (2003). The politics of second-generation reforms. In P. Kuczynski \& J. Williamson (Eds.), After the Washington consensus: Restarting growth and reform in Latin America (pp. 265-303). Institute for International Economics.

North, D. C. (1990). Institutions, institutional change and economic performance. Cambridge University Press. https://doi.org/10.1017/CBO 9780511808678

OECD PMR indicators database. https://www.oecd.org/economy/ reform/indicators-of-product-market-regulation/

Pavletić, I. (2010). Political competition, economic reform and growth: Theory and evidence from transition countries. vdf Hochschulverlag AG.

Pejovich, S. (2018). From socialism in the 1900s to socialism in the 2000s: The rise of liberal socialism. Post-Communist Economies, 30(1), 117-129. https://doi.org/10.1080/14631377.2017.1398527

Pelkmans, J. (2010). Product market reforms in EU Countries: Are the methodology and evidence sufficiently robust? CEPS Working Document No. 332/July 2010.

Persson, T., \& Tabellini, G. (2003). Economic effects of constitutions. MIT Press. https://doi.org/10.7551/mitpress/2591.001.0001

Petak, Z., \& Kotarski, K. (2019). Quo Vadis Croatia? The interplay of institutions, interests and ideas. In Z. Petak \& K. Kotarski (Eds.), Policy-making at the European periphery: The case of Croatia. New Perspectives on South-East Europe (pp. 321-334). Palgrave MacMillan. https://doi.org/ 10.1007/978-3-319-73582-5

Račić, D., \& Cvijanović, V. (2004). Privatisation in Croatia: Initial conditions, processes and implications. In I. Teodorović, Ž. Lovrinčević, M. Nušinović, \& S. Švaljek (Eds.), Hrvatska na putu u Europsku uniju [Croatia on its way to the European Union] (pp. 426-459). Ekonomski institut u Zagrebu.

Robinson, J. A., \& Verdier, T. (2013). The political economy of clientelism. The Scandinavian Journal of Economics, 115(2), 260-291. https://doi. org/10.1111/sjoe.12010 
DRUŠ. ISTRAŽ. ZAGREB GOD. 30 (2021), BR. 4, STR. 675-698

VUČKOVIĆ, V., ŠIMIĆ BANOVIC, R.:

WHO AND WHAT..
Rodrik, D. (2007). One economics, many recipes: Globalization, institutions, and economic growth. Princeton University Press. https://doi.org/10.1515/ 9781400829354

Roubini, N., \& Sachs, J. D. (1989). Political and economic determinants of budget deficits in the industrial democracies. European Economic Review, 33(5), 903-933. https://doi.org/10.1016/0014-2921(89)90002-0 Singer, M. (2009). Buying voters with dirty money: The relationship between clientelism and corruption. APSA 2009 Toronto Meeting Paper. SSRN: https://ssrn.com/abstract $=1449001$

Stiglitz, J. E. (2002). Globalization and its discontents. W. W. Norton \& Company.

Šimić Banović, R. (2019) Uhljeb - a post-socialist homo croaticus: A personification of the economy of favours in Croatia? Post-Communist Economies, 31(3), 279-300, https://doi.org/10.1080/14631377.2018. 1537708

The Heritage Foundation (2019). Index of Economic Freedom database. https://www.heritage.org/index/explore

Tompson, W., \& Dang, T. (2010). Advancing structural reforms in OECD countries: Lessons from twenty case studies. OECD Economics Department Working Papers, No. 757, OECD.

Trantidis, A. (2014). Reforms and collective action in a clientelist system: Greece during the Mitsotakis Administration (1990-93). South European Society and Politics, 19(2), 215-234, https://doi.org/10.1080/ 13608746.2014.893644

Trantidis, A. (2016). Clientelism and economic policy: Hybrid characteristics of collective action in Greece. Journal of European Public Policy, 23(10), 1460-1480, https://doi.org/10.1080/13501763.2015.1088564

Varieties of Democracy (V-Dem) Project. https://doi.org/10.23696/vdemds20 Vidačak, I., \& Kotarski, K. (2019). Interest groups in the policy-making process in Croatia. In Z. Petak \& K. Kotarski (Eds.), Policy-making at the European periphery: The case of Croatia. New perspectives on South-East Europe (pp. 83-104). Palgrave MacMillan. https://doi.org/10.1007/ 978-3-319-73582-5

Voigt, S. (2009). Positive constitutional economics II - A survey of recent developments. Joint Discussion Paper Series in Economics No. 36-2009. https://doi.org/10.2139/ssrn.1358508

WEF (2018). The Global Competitiveness Report 2018 data. http://www3. weforum.org/docs/GCR2018/03CountryProfiles/WEF_GCI4_2018_Profile _Croatia.pdf

Williamson, J. (Ed.) (1994). Political economy of policy reform. Washington, D.C. Institute for International Economics.

World Bank (2019). Database of political institutions. https://datacatalog. worldbank.org/dataset/wps2283-database-political-institutions 
DRUŠ. ISTRAŽ. ZAGREB

GOD. 30 (2021), BR. 4, STR. 675-698

VUČKOVIĆ, V., ŠIMIĆ BANOVIĆ, R.:

WHO AND WHAT...
Tko i što sprječava reforme u Hrvatskoj? - politekonomska analiza

Valentina VUČKOVIĆ

Ekonomski fakultet, Sveučilište u Zagrebu, Zagreb, Hrvatska

Ružica ŠIMIĆ BANOVIĆ

Pravni fakultet, Sveučilište u Zagrebu, Zagreb, Hrvatska

Rad donosi analizu čimbenika koji utječu na proces provođenja reformi u Hrvatskoj, čime se nastoje identificirati glavni razlozi dosadašnjeg (ne)uspjeha u provođenju reformi. Istraživanje se u najvećoj mjeri fokusira na ulogu političkoga sustava, posebno fragmentacije vlade kao jedne od ključnih karakteristika razmjernog izbornog sustava te na klijentelizam. Osim političkih varijabli, u analizu su uključene i ekonomske varijable. Dobiveni rezultati pokazuju da su reforme u Hrvatskoj implementirane tijekom kriza, da koalicijske vlade nisu sklone provođenju reformi te da su klijentelizam i korupcija znatna zapreka provođenju reformi. Nadalje, rezultati upućuju na značajnost političkih ciklusa, uz usporavanje reformske aktivnosti s približavanjem izbora. Dobivenim rezultatima rad pridonosi sadašnjim istraživanjima političke ekonomije reformi u postsocijalističkim zemljama.

Ključne riječi: reforme, Hrvatska, klijentelizam, korupcija, ekonomske slobode

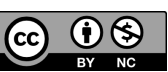

Međunarodna licenca / International License:

Imenovanje-Nekomercijalno / Attribution-NonCommercial 